\title{
The Elementary teacher readiness toward STEM-Based contextual learning in 21st Century Era
}

\author{
Kartimi, Biology Education Department, IAIN Syekh Nurjati, Cirebon, Indonesia, kartimi.iain@gmail.com, \\ ORCID: 0000-0003-3131-3539 \\ Ari Syahidul Shidiq, Science Education Department, Universitas Pendidikan Indonesia, Bandung, \\ Indonesia, arishidiq@upi.edu, ORCID: 0000-0003-4388-5681 \\ Dindin Nasrudin, UIN Sunan Gunung Djati Bandung, dindin.nasrudin@uinsgd.ac.id, ORCID: 0000-0002- \\ 9977-1790
}

\begin{abstract}
Learning in the 21st century is expected to advance knowledge and improve student learning achievement, including at the elementary school level. In addition, learning in the 21st century is also expected to prepare students with 21st century skills that they should have. One learning approach that can be used is STEM-Based contextual learning. Therefore, this study aims to analyze the readiness of elementary school teachers to implement STEM-Based contextual learning in schools. The purposeddesign survey method was used in this study. Questionnaire and observation were used to collect the data. The questionnaire consisted of eighteen open-ended questions to find out the learning process conducted by the teacher, their perceptions of integrated contextual learning, and how the readiness of teachers towards the implementation of STEM-Based contextual learning. Respondents' involeved in this study were 32 elementary school teachers in Bandung, West Java, Indonesia. The result of the study indicated that elementary school teachers were ready to implement STEM-based contextual learning. However, the main problem faced by the teachers to implement STEM-based contextual learning was the difficulty of integrating the subjects and providing contextual aspects related to students' real life. This study was expected to provide an overview of the problems and possibilities in implementing STEM-based contextual learning at the elementary school level.
\end{abstract}

Keywords: 21st Century Skills, Contextual learning, Elementary Student, STEM

Received: 11.12.2019 Accepted: 15.07.2020 Published: 15.01.2021

\section{INTRODUCTION}

Education in the 21st century is in a time of accelerating information and increasing knowledge supported by the application of digital media and technology. Educational institutions are required to be able to innovate in order to facilitate students to have the skills needed in the 21st century (Care, Griffin, \& Wilson, 2018; Griffin, Care, \& McGaw, 2012; Shidiq \& Yamtinah, 2019; Trilling \& Fadel, 2009; Urbani et al., 2017). Research-based knowledge about 21st century skills is dynamic and developing (Fadel, 2016). In line with the increasing interest in teaching and assessing 21st century skills, educational researchers have made significant efforts to improve the quality of learning, especially about cognitive processes in students who emphasize context in learning and assessment. These changes led to the development of a variety of contextual teaching methods in education (Klassen, 2006). Contextual learning and teaching are based on situations of cognition that construct the construction of students' thought processes such as critical thinking, inquiry and problem solving which are adjusted according to the intellectual and social conditions of students. This contextual learning prepares students to learn to face complex problems in the future (Glynn \& Winter, 2004).

Students' ability to solve problems has been the focus of learning today. However, in the 21st century there are several things that need to be integrated to produce logical problem solving. The Science, Technology, Engineering, and Mathematics (STEM) approach can be used as an alternative to develop students' skills. STEM is an interdisciplinary approach that focuses on educating students in four disciplines - science, technology, engineering and mathematics - and integrating these disciplines into contextual problems (Wang, Moore, Roehrig, \& Park, 2011). The 
greater STEM approach opportunities in helping students to solve real world problems by applying concepts from various disciplines as well as critical thinking skills, collaboration, and creativity (Burrows \& Slater, 2015). There have been many integration of STEM with learning in the classroom conducted by researchers (Khatri et al., 2017). Such as the implementaton of STEM in Biology in high school (Saptarani, Widodo, \& Purwianingsih, 2019), in learning chemistry (Sudarmin et al., 2019), and in various laboratory and learning activities (Blotnicky, Franzodendaal, French, \& Joy, 2018; Burrows \& Slater, 2015; Porter, 2018; Shin, Rachmatullah, \& Roshayanti, 2018). The implementation of STEM mostly conducted at the level of high school and university level. Even so, that does not mean STEM cannot be taught at the elementary school level. STEM learning can implemented at the elementary level, but the level of difficulty is not as high as the university level. So it becomes interesting to know the readiness of elementary school teachers to implement STEM-based contextual learning.

Elementary school teachers usually have the responsibility to teach all subject areas, this is one of the advantages in developing student skills and their professional skills, because teachers can plan teaching across fields of study (Bush \& Cook, 2019). Integrated contextual learning has a special role for teachers and students in elementary schools. Through integrated contextual learning the teacher can make learning more meaningful, motivate students and improve their skills (Cook \& Bush, 2018). Most educational research focuses on improving the skills possessed by students, the education curriculum and educational assessment. But few pay attention to the readiness, views and attitudes of teachers in teaching (Shidiq \& Yamtinah, 2019; Tetenbaum \& Mulkeen, 1986). Readiness, views and attitudes of teachers will affect the way they do learning in the classroom (Adams \& Krockover, 1997; Haney, Lumpe, Czerniak, \& Egan, 2002; Harlen \& Holroyd, 2007; Jones \& Levin, 1994; Ucar, 2012). Therefore, the purpose of this study was to analyze the elementary school teachers' readiness to implement STEM-based contextual learning. This study was intended to answer three questions on how the learning management in the classroom carried out by the teacher; the teacher's perception of integrated contextual learning implementation; and the teacher's readiness in implementing STEM-based contextual learning in elementary schools. By conducting this research, it is expected to provide an overview of the problems and opportunities for implementing STEM-based contextual learning at the elementary school level.

\section{METHOD}

\section{Reseach Method}

The purposed-design survey method was used in this study. The survey was intended to analyze the readiness of elementary school teachers to implement STEM-based contextual learning. This survey included observing teachers' learning instruction and distributing questionnaires to analyze their readiness and perceptions on STEM-based contextual learning in elementary school level.

\section{Data collection technique and analysis}

This study used questionnaire and observation to collect the data. The questionnaire consisted of eighteen open-ended questions to reveal the learning process carried out by the teachers, their perceptions of integrated contextual learning, and their readiness to implement STEM-based contextual learning in elementary schools. This questionnaire was designed to answer research questions and to provide comparative data for the observation. The questionnaire blueprint for this study is presented in Table 1. Data from observations and questionnaires were analysed qualitatively and quantitatively. Qualitative data analysis was used to describe the result of observations and questionnaires, while quantitative data analysis technique was used to determine the distribution of questionnaire results. 
Table 1. Questionnaire blueprint

\begin{tabular}{|c|c|c|}
\hline Focus of the question & Indicator & items \\
\hline \multirow[t]{2}{*}{$\begin{array}{l}\text { Learning management in the } \\
\text { classroom }\end{array}$} & Teaching instruction used & 2 \\
\hline & Learning process in the classroom & 3 \\
\hline \multirow[t]{2}{*}{$\begin{array}{l}\text { Teacher's perception of integrated } \\
\text { contextual learning implementation }\end{array}$} & $\begin{array}{l}\text { Contextual learning conducted in the } \\
\text { classroom }\end{array}$ & 1 \\
\hline & $\begin{array}{l}\text { Teacher's perception of the problems and } \\
\text { possibilities in implementing contextual } \\
\text { learning }\end{array}$ & 1 \\
\hline \multirow{4}{*}{$\begin{array}{l}\text { Teacher's readiness in implementing } \\
\text { STEM-based contextual learning in } \\
\text { elementary school }\end{array}$} & Teacher's knowledge about STEM & 4 \\
\hline & $\begin{array}{l}\text { Teacher's perceptions on STEM-based } \\
\text { contextual learning }\end{array}$ & 3 \\
\hline & $\begin{array}{l}\text { The Problems and possibilities in } \\
\text { implementing STEM-based contextual } \\
\text { learning }\end{array}$ & 2 \\
\hline & $\begin{array}{l}\text { Teacher's readiness in implementing STEM- } \\
\text { based contextual learning }\end{array}$ & 2 \\
\hline
\end{tabular}

\section{Respondents}

The Respondents involved in this study were 32 elementary school teachers in Bandung, West Java, Indonesia. These participants came from 23 different elementary schools. Participant selection uses a random sampling technique. The respondents' descriptive data is presented in Table 2.

Tabel 2. Respondents' descriptive data

\begin{tabular}{llccc}
\hline \multicolumn{1}{c}{ Characteristic } & \multicolumn{1}{c}{ Category } & N & \% & SD \\
\hline Gender & Male & 4 & 12.5 & \multirow{2}{*}{16.9} \\
& Female & 28 & 87.5 & \\
Education Level & Bachelor degree & 27 & 84.3 & 15.5 \\
& Master degree & 5 & 15.6 & \\
Teaching grade & 3 & 9.4 & 18.4 \\
& Private & 29 & 90.6 & \\
& State & 4 & 12.5 & \\
& Grade 1 & 4 & 12.5 & \\
& Grade 2 & 4 & 12.5 & 2.9 \\
& Grade 3 & 3 & 9.4 & \\
& Grade 5 & 6 & 18.7 & \\
\hline
\end{tabular}

\section{RESULTS}

Data was obtained from two instruments, namely the learning observation sheet and a questionnaire containing open questions. The result of the teacher learning observation sheet is presented in Table 3, while the result of the teacher's questionnaire is presented in Table 4, 5, and 6, and Figure 1 and 2. 
Table 3. Implementation of learning management

\begin{tabular}{|c|c|c|}
\hline \multirow{2}{*}{$\begin{array}{l}\text { Classroom } \\
\text { teacher }\end{array}$} & \multicolumn{2}{|c|}{ Learning Management Aspects in Classroom } \\
\hline & Learning Media & Learning methods \\
\hline $\begin{array}{l}\text { Teacher of } 1^{\text {st }} \\
\text { Grade }\end{array}$ & $\begin{array}{l}\text { Prepare a Thematic-based lesson plan, with the } \\
\text { textbook package that has been provided }\end{array}$ & $\begin{array}{l}\text { Using lecture and peer tutoring } \\
\text { methods }\end{array}$ \\
\hline $\begin{array}{l}\text { Teacher of } 2^{\text {nd }} \\
\text { Grade }\end{array}$ & $\begin{array}{l}\text { Prepare a thematic-based lesson plan, with the } \\
\text { textbook package that has been provided }\end{array}$ & $\begin{array}{l}\text { Using the cooperative method } \\
\text { with the help of visual aids }\end{array}$ \\
\hline $\begin{array}{l}\text { Teacher of } 3^{\text {rd }} \\
\text { Grade }\end{array}$ & $\begin{array}{l}\text { Prepare a thematic-based lesson plan, with the } \\
\text { textbook package that has been provided }\end{array}$ & $\begin{array}{l}\text { Problem-based learning method } \\
\text { by displaying videos according } \\
\text { to theme }\end{array}$ \\
\hline $\begin{array}{l}\text { Teacher of } 4^{\text {th }} \\
\text { Grade }\end{array}$ & $\begin{array}{l}\text { Prepare a thematic-based lesson plan, with the } \\
\text { textbook package that has been provided }\end{array}$ & $\begin{array}{l}\text { Using problem-based and } \\
\text { project-based learning methods }\end{array}$ \\
\hline $\begin{array}{l}\text { Teacher of } 5^{\text {th }} \\
\text { Grade }\end{array}$ & $\begin{array}{l}\text { Preparing thematic-based lesson plans, } \\
\text { assessment instruments and assessment } \\
\text { guidelines and also use textbook package that has } \\
\text { been provided }\end{array}$ & $\begin{array}{l}\text { Using a scientific approach and } \\
\text { problem based learning }\end{array}$ \\
\hline $\begin{array}{l}\text { Teacher of } 6^{\text {th }} \\
\text { Grade }\end{array}$ & $\begin{array}{l}\text { Preparing thematic-based lesson plans, } \\
\text { assessment instruments and assessment } \\
\text { guidelines and also use the textbook package that } \\
\text { has been provided }\end{array}$ & $\begin{array}{l}\text { Using a scientific approach and } \\
\text { problem-based learning by } \\
\text { utilizing digital multimedia }\end{array}$ \\
\hline
\end{tabular}

Table 4. Teachers' perception toward the implementation of integrated contextual learning

\begin{tabular}{|c|c|}
\hline $\begin{array}{c}\text { Classroom } \\
\text { teacher }\end{array}$ & $\begin{array}{c}\text { Teachers' perception toward on the implementation of integrated contextual } \\
\text { learning }\end{array}$ \\
\hline $\begin{array}{l}\text { Teacher of } \\
1^{\text {st Grade }}\end{array}$ & $\begin{array}{l}\text { Integrated contextual learning is adjusted using learning methods that are appropriate } \\
\text { to the character of students }\end{array}$ \\
\hline $\begin{array}{l}\text { Teacher of } \\
2^{\text {nd }} \text { Grade }\end{array}$ & Delivered using learning media and utilizing the environment as a learning resource \\
\hline $\begin{array}{l}\text { Teacher of } \\
3^{\text {rd Grade }}\end{array}$ & $\begin{array}{l}\text { Integrated contextual learning should be delivered in an integrated manner without } \\
\text { separating per subject }\end{array}$ \\
\hline $\begin{array}{l}\text { Teacher of } \\
4^{\text {th }} \text { Grade }\end{array}$ & Learning must be based on an integrated curriculum \\
\hline $\begin{array}{l}\text { Teacher of } \\
5^{\text {th }} \text { Grade }\end{array}$ & $\begin{array}{l}\text { Integrated contextual learning is delivered through presentations, observations, } \\
\text { discussions, designs, and evaluates }\end{array}$ \\
\hline $\begin{array}{l}\text { Teacher of } \\
6^{\text {th }} \text { Grade }\end{array}$ & $\begin{array}{l}\text { Learning methods and models are adapted to the theme and must be able to choose } \\
\text { material that is intertwined between various fields }\end{array}$ \\
\hline
\end{tabular}

Table 5. Teachers' views on the implementation of STEM-based contextual learning

\begin{tabular}{|c|c|}
\hline $\begin{array}{c}\text { Classroom } \\
\text { teacher }\end{array}$ & Teachers' views on the implementation of STEM-based contextual learning \\
\hline $\begin{array}{l}\text { Teacher of } \\
1 \text { st Grade }\end{array}$ & $\begin{array}{l}\text { STEM-based contextual learning can be implemented by looking for the subject } \\
\text { matter that is appropriate }\end{array}$ \\
\hline $\begin{array}{l}\text { Teacher of } \\
2^{\text {nd }} \text { Grade }\end{array}$ & $\begin{array}{l}\text { STEM-based contextual learning can be implemented, but the teacher must be } \\
\text { creative and master the content of science, technology, engineering, and mathematics }\end{array}$ \\
\hline $\begin{array}{l}\text { Teacher of } \\
3^{\text {rd Grade }}\end{array}$ & $\begin{array}{l}\text { STEM-based contextual learning can be adjusted to the needs of the subject matter to } \\
\text { be delivered }\end{array}$ \\
\hline $\begin{array}{l}\text { Teacher of } \\
4^{\text {th }} \text { Grade }\end{array}$ & $\begin{array}{l}\text { STEM-based contextual learning can be implemented but there must be an } \\
\text { adjustment of basic competencies in the curriculum, because not all basic } \\
\text { competencies in the curriculum can use STEM approach }\end{array}$ \\
\hline $\begin{array}{l}\text { Teacher of } \\
5^{\text {th }} \text { Grade }\end{array}$ & $\begin{array}{l}\text { STEM learning can be carried out depending on the school readiness since all } \\
\text { teachers must understand STEM first and the facilities and infrastructure must be } \\
\text { available }\end{array}$ \\
\hline $\begin{array}{l}\text { Teacher of } \\
6^{\text {th Grade }}\end{array}$ & $\begin{array}{l}\text { STEM learning can be integrated into the learning process through themes that } \\
\text { integrate science, technology, engineering, and mathematics }\end{array}$ \\
\hline
\end{tabular}


Table 6. Problems and Possibilities faced by the elementary school teacher to implement STEMBased Contextual Learning

\begin{tabular}{|c|c|}
\hline $\begin{array}{c}\text { Problems } \\
\end{array}$ & \begin{tabular}{|c|} 
Possibilities \\
\end{tabular} \\
\hline $\begin{array}{l}\text { Dificulty in integrating subjects and provide } \\
\text { contextual aspects related to students' real life }\end{array}$ & $\begin{array}{l}\text { Making teachers and students become more } \\
\text { creative and innovative, improving students' } \\
\text { citical thinking skill, logic, and communicative } \\
\text { skill in accordance with the skills needed in } 21^{\text {st }} \\
\text { century }\end{array}$ \\
\hline $\begin{array}{l}\text { Not all students understand and are capable to } \\
\text { formulate problems systematically so that the } \\
\text { STEM-based contextual learning was not } \\
\text { optimum }\end{array}$ & Students learn to solve their problems \\
\hline Require a lot of time and supportive facilities & $\begin{array}{l}\text { Students and teacher are involved in creative, } \\
\text { inovative, communicative, dan colaborative } \\
\text { learning process }\end{array}$ \\
\hline $\begin{array}{l}\text { Mathematics and Science are separated subjects } \\
\text { in elementary school }\end{array}$ & $\begin{array}{l}\text { Students are trained to analyse problems using } \\
\text { various approaches: Science, technology, } \\
\text { engineering, arts, or Mathematics. }\end{array}$ \\
\hline $\begin{array}{l}\text { Teachers need extended guidance and training } \\
\text { on STEM-based contextual learning process }\end{array}$ & $\begin{array}{l}\text { Teachers are more developed. They teach } \\
\text { students to be independent to find new things in } \\
\text { education to prepare their future. }\end{array}$ \\
\hline
\end{tabular}

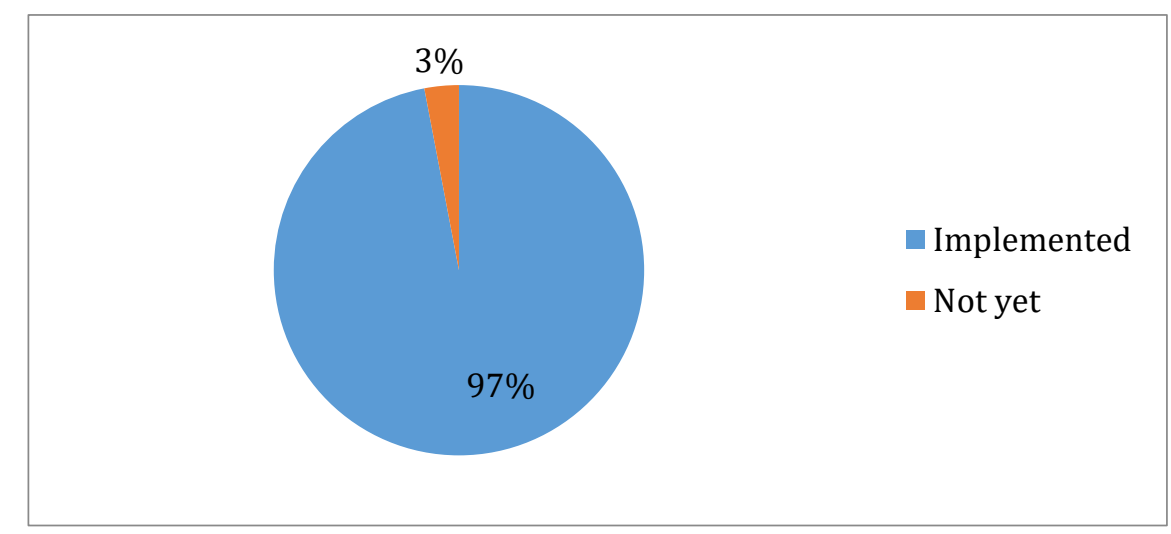

FIGURE 1. Teachers' Integrated Thematic Learning Implementation

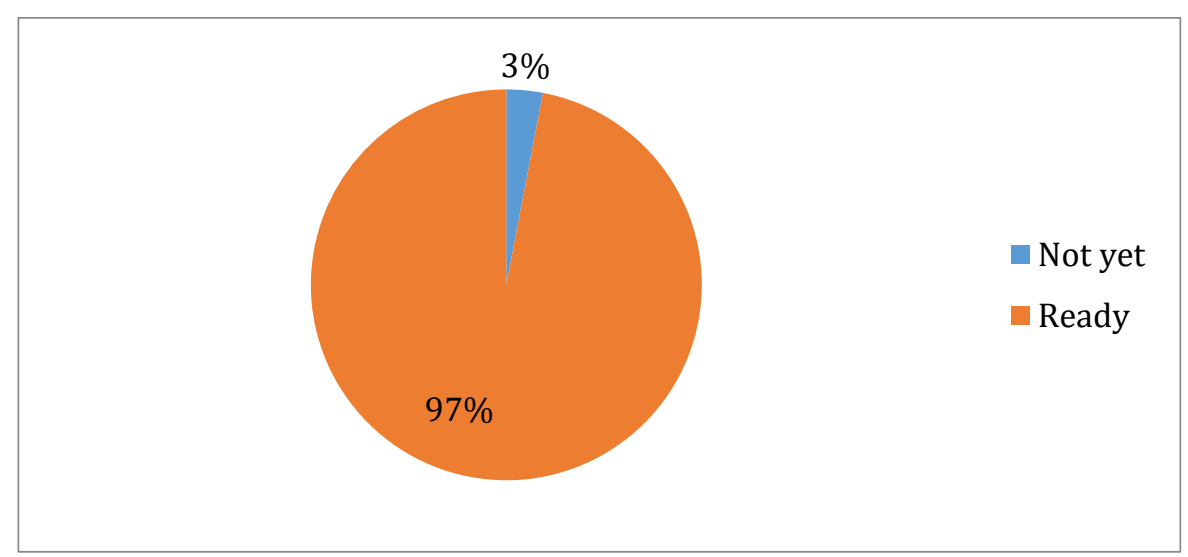

FIGURE 2. Teachers' Readiness to Implement STEM-based contextual learning 


\section{DISCUSSION and CONCLUSION}

\section{The learning process that has been used by the teacher}

Indonesian curriculum policy requires elementary schools to implement contextual learning integrated with a theme or what is commonly referred to as thematic learning. Thematic learning is assessed as a way to contextualize material from various subjects. In addition, integrated thematic learning can also orient students' learning ways to be more concrete and facilitate students and teachers to get cooperative and interactive learning opportunities in the classroom (Lesgold, 2004; Min, 2012). The learning process in elementary schools in Indonesia has implemented this integrated contextual learning with themes. Themes provide benefits to students because the subject matter presented is closer to their daily lives (Rahma, 2018). The theme for each level from grade 1 to grade 6 is determined by the government through distributed textbooks. The books distributed are used by the teacher as a guide for planning and evaluating the learning undertaken (Ain \& Rahutami, 2018).

Research by Atmojo \& Kurniawati (2018) showed that embedding certain concepts in students can be packaged in the form of books that cover all of these concepts. In addition to the proper use of books, the appropriateness between planning and applying methods in class also needs to be considered. So that the material contained in the thematic books can be delivered properly. In this study, observations were made on the management of learning undertaken by teachers and their responses to integrated contextual learning. The results of research on learning management conducted by teachers are presented in Table 3.

Table 3 shows that all teachers had used the textbook package that had been provided at the planning stage of the learning tools. So they have guidelines in presenting learning. In addition, teachers also prepare instruments and assessment guidelines. But what varies in Table 3 is when implementing learning. The results of observation show that the higher the grade level, the more complex the method used. At grade 1, the lecture method and peer tutors are chosen. The peer tutoring method is a place for students to develop the ability to find and develop concepts. Because in the learning process interaction occurs between students in solving problems from the teacher (Ahdiyat \& Sarjaya, 2015) The 21st century skill that is being taught at this stage is communication. This skill is very important because this skill is used to express thoughts, ideas or any information (Redhana, 2019).

A 21st Century skill, collaboration, began to be trained at grade 2 using cooperative method. Good collaboration encourages active student participated in generating more flexible thinking and finding steps to solve a problem (Le, Janssen, \& Wubbels, 2018). By learning to work together, the purpose of learning is not just looking for value, but understanding concepts, selfconfidence, life experiences and social interactions that will help students live their lives (Rosita \& Leonard, 2015).

At grade 3 through grade 6 the teacher begins to include problems in his learning. This is intended to practice 21 st century skills, namely creative thinking and critical thinking skills. At the grade 3 and grade 4 levels, these skills are developed with the help of problems whose solution makes a project. Mayasari et al (2016) research results showed that Problem based learning and project-based learning are learning models with constructivism approaches and have been reported to be able to train 21 st century skills to students. The teacher chooses simple problems so that it is easy for students to make their solutions. At the grade 5 and 6 , the skills are re-trained using a scientific approach. This approach makes students learn to do a systematic process to get a conclusion (Dewantara, 2020).

Based on the observation sheet it can be seen that the teacher begins to gradually practice 21st century skills. In addition, Table 3 also shows that learning conducted in elementary schools in Bandung has led to an integrated contextual thematic learning. Figure 1 showed that $97 \%$ of the teachers had implemented integrated contextual thematic learning. However, there were differences for the preparation of learning and learning methods used at each grade level. Scientific learning methods only appear in grades 5 and 6 . Likewise, the use of multimedia is only in grade 6. Another problem arisen was the use of thematic textbooks provided by the government. This makes the lack of creativity of teachers to provide themes that are closer to 
student life. A theme raised from natural and social phenomena that are close to students will make learning intact and more meaningful (Ain \& Rahutami, 2018; Hayes, 1989; MacQuarrie, Nugent, \& Warden, 2015).

Research on thematic learning has been conducted by many experts, such as research on the success of integrated thematic learning to improve the quality of learning (Lipson, Valencia, Wixson, \& Peters, 1993), Thematic learning with inquiry methods that can improve student literacy (Shanahan, 1997), theme mapping with thematic maps in elementary schools (Michaelidou, Nakos, \& Filippakopoulou, 2007; Trifonoff, 1995) and research on the effects of thematic learning, direct science teaching with a textbook approach for students (McCarthy, 2005).

The lack of variety of learning media and learning methods used by teachers is an indicator of teacher readiness to conduct thematic learning. Innovations in the media and learning methods have been done by researchers, such as the use of game methods to improve the literacy of elementary school students (Amir, Mufarikhah, Wahyuni, Nasrun, \& Rudyanto, 2019), use scientific methods to improve geometric thinking skills (Novita, Putra, \& Johar, 2019), use a five-tiered assessment instrument to identify elementary school students' misconceptions (Anam, Widodo, Sopandi, \& Wu, 2019), the use of contextual learning approaches (Glynn \& Winter, 2004; Selvianiresa \& Prabawanto, 2017; Yuliana, Wiryawan, \& Riyadi, 2018) and application of STEAM (Science, Technology, Engineering, Art, and Mathematics) (Yoon \& Baek, 2018).

\section{Teacher readiness to implement STEM-based contextual learning at the elementary school}

Contextual learning has a focus on the delivery of knowledge relevant to the concept as well as the student life. The theme used in contextual learning motivates students to make connections between knowledge and its application to social life (Glynn \& Winter, 2004). Contextual learning is a learning system based on the philosophy that students can receive lessons if they can understand the meaning of academic material and schoolwork, and they can associate new information with their previous knowledge and experience. This is in line with the conscience of humans who always want to find meaning. Contextual learning invites students to meaningfully link schoolwork in daily life. When students see the meaning in the assignment to be done, students will receive the lesson and remember it (Johar, Agussalim, Ikhsan, \& Zaura, 2018). STEM-based contextual learning makes learning more meaningful. STEM learning has been applied at various levels of the school, but there are still not many who conducted it in elementary schools (Akaygun \& Aslan-Tutak, 2016; Fassa, Tytler, Freeman, \& Roberts, 2013; Jho, 2016; Madden et al., 2013). By considering the success and benefits of STEM learning at various school levels, it becomes important to know the readiness of elementary school teachers to implement STEM integrated contextual learning. Teachers' perception toward integrated contextual learning ware presented in Table 4. Teacher's views on the implemantation of integrated contextual learning STEM ware presented in Table 5

Teachers' views on the implementation of integrated contextual learning were very diverse (Milner, Templin, \& Czerniak, 2011). However, these teachers indicated that implementing learning requires support from various aspects. The first-grade teacher said that integrated contextual learning should be adjusted to the character of students. Teacher readiness in recognizing student characteristics is important because it influences the way the teacher teaches (Haney et al., 2002; Yamtinah, Masykuri, \& Shidiq, 2017). The second-grade teachers emphasized the use of the environment as a learning resource. In contextual learning it is very important to present learning resources that are close to students, so students are easier to recognize problems and relate them to concepts (O'Sullivan, 2006). The third and fourth grade teachers have the same view which was conveying material in an integrated way. This is intended so that students are more flexible in preparing explanations for each problem given by the teacher. On the other hand, the 5th and 6th grade teachers assume that integrated contextual learning should be taught using scientific methods so that the selection of problems related to other disciplines. The teachers' views were in line with other study which found out that 
innovative and contextual approach significantly affect the learning process in elementary school (Glynn \& Winter, 2004).

Accuracy in choosing and delivering material has been keys in achieving learning objectives. In the 21st century students need to have special skills that can be developed through learning (Rusdin, 2018). Therefore STEM is an approach that needs to be integrated in learning (Amanda Roberts, 2012). Integrating STEM with contextual learning can be an opportunity for learning approaches which can answer the 21st century challenges. Therefore, it is essential to know the elementary school teachers' readiness, views and abilities to implement this approach.

The teachers argued that $21^{\text {st }}$ century skills can be improved gradually by using integrated conteaxtual learning. However, if it is associated with the STEM approach, students will have better skills. Therefore, Table 5 shows the teacher's views on integrated STEM contextual learning. The teachers have diverse views about the implementation of the learning. Teachers from grade 1 to grade 3 argue that knowledge of material content is the core of STEM learning. Teachers are required to have good content abilities, because they will integrate not only one knowledge but also collaborate with other knowledge (Wang et al., 2011).

The 4th grade teacher has a different view from the three previous teacher levels. Guru kelas 4 percaya pendekatan STEM dapat dilakukan, namun harus memperhatikan kompetensi dasar yang ingin dicapai. Dalam pendekatan STEM, integrasi terjadi dalam konteks mengadaptasi keempat bidang STEM dalam hal konten, atau menggunakan satu area sebagai pusat dan yang lainnya sebagai konteks dalam pembelajaran (Gül \& Taşar, 2020). Oleh karena ini, pembelajaran STEM membutuhkan suatu kompetensi dasar sebagai target atau output dari pembelajaran yang dilakukan. Sebagai panduan, keterampilan abad 21 bisa dijadikan acuan sebagai luaran dari pembelajaran STEM (Gül \& Taşar, 2020).

Grade 5 teachers have a holistic view when they want to implement STEM-based contextual learning. Teachers at this level argue that the good learning process depends on the readiness of the teacher and the school. Teachers who are content and pedagogically prepared and students who are able to adapt the new learning approach are two essential things that must be prepared in implementing this learning approach (Radloff \& Guzey, 2016). STEM learning encourages teachers to create learning environments based on constructivist approaches that allow students to learning by doing (Gül \& Taşar, 2020; Toran, Aydın, \& Etgüer, 2020). Therefore, teachers' knowledge and readiness to implement STEM-based contextual learning is important.

Grade 6 teachers have a theoretical view on the application of STEM learning. However, the grade 6 teachers focused on the theme selection. Thus, this must also be accompanied by teacher knowledge about the material presented. Learning using STEM which integrates Science, Technology, Engineering, and Mathematics is a difficult job (Bybee, McCrae, \& Laurie, 2009; Sanders, 2009). Therefore, at the elementary school level, a careful selection of themes that can integrate STEM components is needed. This is in line with various studies which emphasize that content selection and learning context in STEM are important (Baines, 2015; Harris \& de Bruin, 2018; Nedungadi, Raman, \& McGregor, 2013). If it can be executed well, it is possible that STEMbased contextual learning will create a competitive generation to compete each other. Basically, a variety of skills in the 21st century can be developed by students through active, creative and innovative learning; therefore STEM-based contextual learning is very relevant. The purpose of STEM-based contextual learning is to prepare students with a particular learning environment to implement their knowledge and skills needed in the 21st century (Bybee et al., 2009). STEMbased contextual learning also provides interdisciplinary knowledge and skills and prepares students to face knowledge-based world economic competition (Koenig, 2011; National Research Council, 2012). In the 21st century, students must be able to generate new knowledge and apply it to new situations and problems rather than using the existing knowledge easily (Gül \& Taşar, 2020; Wagner, 2011).

The problems and posibilities faced by elementary school teachers can be seen in Table 6 . The main problem faced by the teachers in implementing STEM-based contextual learning was integrating the subjects and providing contextual aspects relevant to the students' real life. Teachers were used to conventional teaching which separate the subjects. This idea is supported by various studies on teachers' difficulty in integrating STEM caused by the teachers' orientation 
to their own discipline. Mathematics teacher only oriented to Mathematics, and Sience teachers only oriented to Science (El-Deghaidy \& Mansour, 2015; Nadelson et al., 2013; Stohlmann, Moore, \& Roehrig, 2012). Accordingly, to overcome those challenges, teachers need to acquire an adequate pedagogical content knowledge (El-Deghaidy \& Mansour, 2015). This skill can help teachers to decide the crosscutting concepts and the core idea of the learning (Chesnutt et al., 2019).

Besides problems, teachers were also optimistic to the opportunities for implementing STEM-based contextual learning. They believed that implementing STEM-based contextual learning can help students to think creatively, critically, innovatively and train them to analyze problems using various approaches: Science, Technology, Engineering, and Mathematics. This view is supported by various references from previous studies which proved that STEM learning was able to improve creative thinking skills (Harris \& de Bruin, 2018; Megawan \& Istiyono, 2019), critical thinking and problem solving skills (Soros, Ponkham, \& Ekkapim, 2018), innovation skills (El Mawas et al., 2019; Paredes \& Vazquez, 2019) and other skills needed in 21st century (Crumbaugh, Vellom, Kline, \& Tsang, 2004; Hurson, Sedigh, Miller, \& Shirazi, 2011 ; Munsell, 2020).

The teacher optimism was supported by the survey data presented in Figure 2. There were $97 \%$ of teachers were willing to implement STEM-based contextual learning. Therefore, it can be concluded that teachers were ready to implement STEM-based contextual learning in elementary schools. However, the teacher argued that they found problems in identifying themes in elementary school curriculum appropriate for STEM-based contextual learning. Therefore, it is suggested that policy makers and teachers administer content analysis on the current curriculum to create themes which promote STEM-based contextual learning. Furthermore, the teachers also confirmed that the lack of facilities to improve their knowledge and skills in implementing STEMbased contextual learning. Thus, it is recommended to conduct training and education on STEMbased contextual learning for teachers.

This study presents an overview of problems, possibilities, and teacher readiness in implementing STEM-based contextual learning. However, the small number of respondents and the limited scope of the survey area could be the limitations of the current study. Incrasing the number of respondents, expanding survey area coverage, and using valid instruments for further research will increase the validity of the data obtained to be generalized. Lastly, further study on the effectiveness of implementing STEM-based contextual learning in elementary schools is still needed.

\section{REFERENCES}

Adams, P. E., \& Krockover, G. H. (1997). Beginning Science Teacher Cognition and Its Origins in the Preservice Secondary Science Teacher Program. Journal of Research in Science Teaching, 34(6), 633-653.

Ahdiyat, M., \& Sarjaya. (2015). Metode Tutor Sebaya untuk Meningkatkan Hasil Belajar Matematika Pada Materi Pengolahan Data. Formatif: Jurnal Ilmiah Pendidikan MIPA, 4(1), 71-79. https://doi.org/10.30998/formatif.v4i1.141

Ain, N., \& Rahutami, R. (2018). Theme network in thematic learning in elementary school. Journal of Physics: Conference Series, 1013(1). https://doi.org/10.1088/1742-6596/1013/1/012065

Akaygun, S., \& Aslan-Tutak, F. (2016). STEM Images Revealing STEM Conceptions of Pre-Service Chemistry and Mathematics Teachers. International Journal of Education in Mathematics, Science and Technology, 4(1), 56. https://doi.org/10.18404/ijemst.44833

Amanda Roberts. (2012). A Justification for STEM Education. Technology and Engineering Teachere, May/June(June), 1-5. https://doi.org/10.1126/science.1201783

Amir, M. F., Mufarikhah, I. A., Wahyuni, A., Nasrun, \& Rudyanto, H. E. (2019). Developing 'fort defending' game as a learning design for mathematical literacy integrated to primary school curriculum in indonesia. Elementary Education Online, 18(3), 1081-1092. https://doi.org/10.17051/ilkonline.2019.610145

Anam, R. S., Widodo, A., Sopandi, W., \& Wu, H. K. (2019). Developing a five-tier diagnostic test to identify students' misconceptions in science: an example of the heat transfer concepts. Elementary Education Online, 18(3), 1014-1029. https://doi.org/10.17051/ilkonline.2019.609690

Atmojo, S. E., \& Kurniawati, W. (2018). Pengembangan Buku Ajar Tematik Bervisi Sets Untuk Menanamkan Konsep Sustainable and Renewable Energy Siswa Sekolah Dasar. Refleksi Edukatika: Jurnal Ilmiah 
Kependidikan, 8(2), 156-162. https://doi.org/10.24176/re.v8i2.2354

Baines, L. (2015). Emerging Technologies for STEAM Education. Emerging Technologies for STEAM Education. https://doi.org/10.1007/978-3-319-02573-5

Blotnicky, K. A., Franz-odendaal, T., French, F., \& Joy, P. (2018). A study of the correlation between STEM career knowledge, mathematics self- efficacy, career interests, and career activities on the likelihood of pursuing a STEM career among middle school students. International Journal of STEM Education, 5(22), 1-15.

Burrows, A., \& Slater, T. (2015). A Proposed Integrated STEM Framework for Contemporary Teacher Preparation. Teacher Education and Practice, 28(2), 318-330.

Bush, S. B., \& Cook, K. L. (2019). Structuring STEAM Inquiries: Lessons Learned from Practice. In M. S. Khine \& S. Areepattamannil (Eds.), STEAM Education: Theory and Practice (pp. 19-20). Cham: Springer.

Bybee, R., McCrae, B., \& Laurie, R. (2009). PISA 2006: An assessment of scientific literacy. Journal of Research in Science Teaching, 46(8), 865-883. https://doi.org/10.1002/tea.20333

Care, E., Griffin, P., \& Wilson, M. (2018). Assessment and Teaching of 21st Century Skills. (E. Care, P. Griffin, \& M. Wilson, Eds.). Cham: Springer International Publishing. https://doi.org/10.1007/978-3-319-65368-6

Chesnutt, K., Gail Jones, M., Corin, E. N., Hite, R., Childers, G., Perez, M. P., ... Ennes, M. (2019). Crosscutting concepts and achievement: Is a sense of size and scale related to achievement in science and mathematics? Journal of Research in Science Teaching, 56(3), 302-321. https://doi.org/10.1002/tea.21511

Cook, K. L., \& Bush, S. B. (2018). Design thinking in integrated STEAM learning: Surveying the landscape and exploring exemplars in elementary grades. School Science AndMathematics, (January), 1-11. https://doi.org/10.1111/ssm.12268

Dewantara, I. P. M. (2020). Curriculum changes in Indonesia: Teacher constraints and students of prospective teachers' readiness in the implementation of thematic learning at low grade primary school. Elementary Education Online, 19(2), 1047-1060. https://doi.org/10.17051/ilkonline.2020.696686

El-Deghaidy, H., \& Mansour, N. (2015). Science Teachers' Perceptions of STEM Education: Possibilities and Challenges. International Journal of Learning and Teaching, 1(1), 51-54. https://doi.org/10.18178/ijlt.1.1.51-54

Fadel, C. (2016). 21st Century Competencies. Independent School Magazine, (Winter), 1-70. Retrieved from http://www.nais.org/Magazines-Newsletters/ISMagazine/Pages/Twenty-First-CenturyCompetencies.aspx\#1

Fassa, S. M., Tytler, R., Freeman, B., \& Roberts, K. (2013). STEM: Country comparisons. Report for the Australian Council of Learned Academies. The Australian Council of Learned Academies, 178. https://doi.org/ISBN 978 0987579805

Glynn, S. N., \& Winter, L. K. (2004). Contextual Teaching and Learning of Science in Elementary Schools. Journal of Elementary Science Education, 16(2), 51-63.

Griffin, P., Care, E., \& McGaw, B. (2012). Assessment and Teaching of 21st Century Skills. (P. Griffin, B. McGaw, \& E. Care, Eds.). Dordrecht: Springer Netherlands. https://doi.org/10.1007/978-94-007-2324-5

Gül, K. S., \& Taşar, M. F. (2020). A review of researches on stem in preservice teacher education. Elementary Education Online. https://doi.org/10.17051/ilkonline.2020.689682

Haney, J. J., Lumpe, A. T., Czerniak, C. M., \& Egan, V. (2002). From Beliefs to Actions: The Beliefs and Actions of Teachers Implementing Change. Journal of Science Teacher Education, 13(3), 171-187.

Harlen, W., \& Holroyd, C. (2007). Primary teachers' understanding of concepts of science: impact on confidence and teaching. International Journal of Science Education, 19(1), 93-105. https://doi.org/10.1080/0950069970190107

Harris, A., \& de Bruin, L. R. (2018). Secondary school creativity, teacher practice and STEAM education: An international study. Journal of Educational Change, 19(2), 153-179. https://doi.org/10.1007/s10833-0179311-2

Hayes, H. (1989). Intenlisciplinary Curriculum : Design and Implementation.

Jho, H. (2016). An analysis of STEM / STEAM teacher education in Korea with a case study of two schools from a community of practice perspective. Eurasia Journal of Mathematics, Science \& Technology Education, 12(7), 1843-1862. https://doi.org/10.12973/eurasia.2016.1538a

Johar, R., Agussalim, Ikhsan, M., \& Zaura, B. (2018). The development of learning materials using contextual teaching learning (CTL) approach oriented on the character education. Journal of Physics: Conference Series, 1088, 0-6. https://doi.org/10.1088/1742-6596/1088/1/012039

Jones, C., \& Levin, J. (1994). Primary/elementary teachers' attitudes toward science in four areas related to gender differences in students' science performance. Journal of Elementary Science Education, 6(I), 46-66.

Khatri, R., Henderson, C., Cole, R., Froyd, J. E., Friedrichsen, D., \& Stanford, C. (2017). Characteristics of wellpropagated teaching innovations in undergraduate STEM. International Journal of STEM Education, 4(1). https://doi.org/10.1186/s40594-017-0056-5

Klassen, S. (2006). Contextual assessment in science education: Background, issues, and policy. Science Education, 90(5), 820-851. https://doi.org/10.1002/sce.20150

Koenig, J. A. (2011). Assessing 21st Century Skills: Summary of a Workshop. National Academies Press. Washington DC: National $\quad$ Research $\quad$ Council. $\quad$ Retrieved from 
http://search.ebscohost.com/login.aspx?direct=true\%7B\&\%7Ddb=eric\%7B\&\%7DAN=ED554571\%7B\& $\% 7$ Dsite $=$ ehost-

live\%7B\&\%7Dscope=site\%7B\%25\%7D5Cnhttp://www.nap.edu/catalog.php?record\%7B_\%7Did=1321 5\%5Cnhttp://search.ebscohost.com/login.aspx?direct=true\&db=eric\&AN=ED55

Le, H., Janssen, J., \& Wubbels, T. (2018). Collaborative learning practices: teacher and student perceived obstacles to effective student collaboration. Cambridge Journal of Education, 48(1), 103-122. https://doi.org/10.1080/0305764X.2016.1259389

Lesgold, A. (2004). Contextual requirements for constructivist learning. International Journal of Educational Research. https://doi.org/10.1016/j.ijer.2005.08.014

Lipson, M. Y., Valencia, S. W., Wixson, K. K., \& Peters, C. W. (1993). Integration and Thematic Teaching: Integration to Improve Teaching and Learning. Language Arts, 70(4), 252-263.

MacQuarrie, S., Nugent, C., \& Warden, C. (2015). Learning with nature and learning from others: nature as setting and resource for early childhood education. Journal of Adventure Education and Outdoor Learning, 15(1), 37-41. https://doi.org/10.1080/14729679.2013.841095

Madden, M. E., Baxter, M., Beauchamp, H., Bouchard, K., Huff, M., Ladd, B., ... Plague, G. (2013). Rethinking STEM Education : An Interdisciplinary STEAM Curriculum. Procedia - Procedia Computer Science, 20, 541-546. https://doi.org/10.1016/j.procs.2013.09.316

Mayasari, T., Kadarohman, A., Rusdiana, D., \& Kaniawati, I. (2016). Apakah Model Pembelajaran Problem Based Learning Dan Project Based Learning Mampu Melatihkan Keterampilan Abad 21? Jurnal Pendidikan Fisika Dan Keilmuan (JPFK), 2(1), 48-55. https://doi.org/10.25273/jpfk.v2i1.24

McCarthy, C. B. (2005). Effects of thematic-based, hands-on science teaching versus a textbook approach for students with disabilities. Journal of Research in Science Teaching, 42(3), 245-263. https://doi.org/10.1002/tea.20057

Michaelidou, E., Nakos, B., \& Filippakopoulou, V. (2007). The Ability of Elementary School Children to Analyse General Reference and Thematic Maps. Cartographica: The International Journal for Geographic Information and Geovisualization, 39(4), 65-88. https://doi.org/10.3138/k63j-1260-8416-863w

Milner, A. R., Templin, M. A., \& Czerniak, C. M. (2011). Elementary Science Students' Motivation and Learning Strategy Use: Constructivist Classroom Contextual Factors in a Life Science Laboratory and a Traditional Classroom. Journal of Science Teacher Education, 22(2), 151-170. https://doi.org/10.1007/s10972-0109200-5

Min, K. C. (2012). Teachers ' Understanding and Practice towards Thematic Approach in Teaching Integrated Living Skills ( ILS ) in Malaysia. International Journal of Humanities and Social Science, 2(23), 273-281.

Nadelson, L. S., Callahan, J., Pyke, P., Hay, A., Dance, M., \& Pfiester, J. (2013). Teacher STEM perception and preparation: Inquiry-based stem professional development for elementary teachers. Journal of Educational Research, 106(2), 157-168. https://doi.org/10.1080/00220671.2012.667014

National Research Council. (2012). A Framework for K-12 Science Education. Social Sciences. Washington DC: The National Academic Press. https://doi.org/10.1016/0165-0114(95)00092-5

Nedungadi, P., Raman, R., \& McGregor, M. (2013). Enhanced STEM learning with Online Labs: Empirical study comparing physical labs, tablets and desktops. Proceedings - Frontiers in Education Conference, FIE, 15851590. https://doi.org/10.1109/FIE.2013.6685106

Novita, R., Putra, M., \& Johar, R. (2019). Using scientific methods to enhance early childhood students' geometry thinking. Elementary Education Online, 2078-2093. https://doi.org/10.17051/ilkonline.2019.639421

O'Sullivan, M. (2006). Lesson observation and quality in primary education as contextual teaching and learning processes. International Journal of Educational Development, 26(3), 246-260. https://doi.org/10.1016/j.ijedudev.2005.07.016

Porter, L. A. (2018). 3D Printable Resources for Engaging STEM Students in Laboratory Learning Activities and Outreach Programs: Inexpensive and User-Friendly Instrument Kits for Educators. Materials Research Society, 2937-2942. https://doi.org/10.1557/adv.2018.

Radloff, J., \& Guzey, S. (2016). Investigating Preservice STEM Teacher Conceptions of STEM Education. Journal of Science Education and Technology, 25(5), 759-774. https://doi.org/10.1007/s10956-016-9633-5

Rahma, F. I. (2018). PENGEMBANGAN BAHAN AJAR TEMATIK INTEGRATIF BERBASIS KARAKTER DENGAN MULTIMEDIA. Pancawahana: Jurnal Studi Islam, 13(1), 91-95.

Redhana, I. W. (2019). Mengembangkan Keterampilan Abad Ke-21 Dalam Pembelajaran Kimia. Jurnal Inovasi Pendidikan Kimia, 13(1), 39-53.

Rosita, I., \& Leonard, L. (2015). Meningkatkan Kerja Sama Siswa Melalui Pembelajaran Kooperatif Tipe Think Pair Share. Formatif: Jurnal Ilmiah Pendidikan MIPA, 3(1), 1-10. https://doi.org/10.30998/formatif.v3i1.108

Rusdin, N. M. (2018). Teachers' Readiness in Implementing 21st Century Learning. International Journal of Academic Research in Business \& Social Sciences, 8, 1293-1306.

Sanders, M. (2009). STEM, STEM education, STEMmania.

Saptarani, D., Widodo, A., \& Purwianingsih, W. (2019). Biology teachers and high school students perceptions 
about STEM learning. Journal of Physics: Conference Series, 1157(4), 0-6. https://doi.org/10.1088/1742$6596 / 1157 / 4 / 042007$

Selvianiresa, D., \& Prabawanto, S. (2017). Contextual Teaching and Learning Approach of Mathematics in Primary Schools. Journal of Physics: Conference Series, 895(1). https://doi.org/10.1088/1742-6596/895/1/012171

Shanahan, T. (1997). Reading-Writing Relationships, Thematic Units, Inquiry Learning In Pursuit of Effective Integrated Literacy Instruction. The Reading Teacher, 51(1), 12-19.

Shidiq, A. S., \& Yamtinah, S. (2019). Pre-service chemistry teachers' attitudes and attributes toward the twentyfirst century skills. Journal of Physics: Conference Series, 1157(042014), 1-8. https://doi.org/10.1088/1742-6596/1157/4/042014

Shin, S., Rachmatullah, A., \& Roshayanti, F. (2018). Career motivation of secondary students in STEM : a crosscultural study between Korea and Indonesia. International Journal for Educational and Vocational Guidance, 18(2), 203-231. https://doi.org/10.1007/s10775-017-9355-0

Stohlmann, M., Moore, T., \& Roehrig, G. (2012). Considerations for Teaching Integrated STEM Education. Journal of Pre-College Engineering Education Research, 2(1), 28-34. https://doi.org/10.5703/1288284314653

Sudarmin, S., Kurniawan, C., N, P., . M., . A., \& I, N. (2019). The Implementation of Chemical Project Learning Model Integrated with Ethno-Stem Approach on Water Treatment Topic Using Kelor (Moringa oleifera) Seed Extract As Bio-Coagulant. KnE Social Sciences, 2019, 492-501. https://doi.org/10.18502/kss.v3i18.4740

Tetenbaum, T. J., \& Mulkeen, T. A. (1986). Designing Teacher Education for the Twenty-First Century. The Journal of Higher Education, 57(6), 621-636. https://doi.org/10.2307/1981196

Toran, M., Aydın, E., \& Etgüer, D. (2020). Investigating the effects of STEM enriched implementations on school readiness and concept acquisition of children. Elementary Education Online, 19(1), 299-309. https://doi.org/10.17051/ilkonline.2020.656873

Trifonoff, K. M. (1995). Going beyond location: Thematic maps in the early elementary grades. Journal of Geography, 94(2), 368-374. https://doi.org/10.1080/00221349508979745

Trilling, B., \& Fadel, C. (2009). 21st Century Skills. San Francisco: John Wiley \& Sons.

Ucar, S. (2012). How Do Pre-Service Science Teachers ' Views on Science, Scientists, and Science Teaching Change Over Time in a Science Teacher Training Program ? Journal of Science Education and Technology, 21, 255-266. https://doi.org/10.1007/s10956-011-9311-6

Urbani, J. J. M., Truesdell, E., Urbani, J. J. M., Roshandel, S., Michaels, R., Truesdell, E., ... Truesdell, E. (2017). Assessment and Teaching of 21st Century Skills. Educacion Quimica, 1(1), 1709-1716. https://doi.org/10.1016/j.sbspro.2009.01.303

Wagner, T. (2011). Rigor Redefined. Overcoming the Global Achievement Gap. In Yrittäjyyskasvatus perus- ja toisella asteella (pp. 107-125). Kerhokeskus - koulutyön tuki ry.

Wang, H.-H., Moore, T. . J., Roehrig, G. H., \& Park, M. S. (2011). STEM integration: Teacher perceptions and practice. Journal of Pre-College Engineering Education Research, 1(2), 1-13. https://doi.org/10.5703/1288284314636

Yamtinah, S., Masykuri, M., \& Shidiq, A. S. (2017). Gender Differences in Students ' Attitudes toward Science : An Analysis of Students ' Science Process Skill using Testlet Instrument. AIP Conference Proceedings, 1868(030003), 1-6. https://doi.org/10.1063/1.4995102

Yoon, M. B., \& Baek, J. E. (2018). Development and application of the STEAM education program based on the soccer robot for elementary students. International Journal of Mobile and Blended Learning, 10(3), 11-22. https://doi.org/10.4018/IJMBL.2018070102

Yuliana, M., Wiryawan, S. A., \& Riyadi. (2018). The development of thematic materials using project based learning for elementary school. Journal of Physics: Conference Series, 1022(1). https://doi.org/10.1088/1742-6596/1022/1/012018 